\title{
Rugova as a Literary Scholar
}

\author{
Albanë Mehmetaj \\ Ph.D., Teaching Assistant, \\ University of Prishtina "Hasan Prishtina", Kosovo; \\ Faculty of Philology, Department of Albanian Literature, \\ Prishtina, Kosovo
}

\section{DOI: https://doi.org/10.36941/jesr-2020-0o64}

\begin{abstract}
This paper analyses the literary studies of dr. Ibrahim Rugova, one of the most known modern Albanian scholar, who in fact is known all over the world as e Kosovo political leader and founder of the independent state of Kosovo. But he is not known in the field of literary studies as in the political field, so our main aim is to present him as a scholar. Rugova's work as a literally scholar started with his "Lyrical Touch" (1971), which features almost all poetic literary interpretations, to follow with his "Toward Theory", which sets off Rugova's path to theoretical-literary research. Specifically, the problem treated in this book captures theoretical problems of literature and centered on the proposal for "artistic text" and "open work," which proves that Rugova never intended to close the discussed issues, but aims at providing possible solutions. In this sense, his theory goes to the point of view of literature as "differentia specifica," as a special artistic product. In the case of this concept, apart from treating it theoretically, Rugova breaks it apart from Albanian literature, comparing it with the models of world knowledge. Such an effort seeks to differentiate literature as a particular gender, as an intellectual product, as quest of the "literary essence".
\end{abstract}

Keywords: Literary criticism, differrentia specifica, albanien studies, directions and premises, aesthetic rejection

\section{Introduction}

Dr. Ibrahim Rugova is widely recognized as political and spiritual leader of Kosovo Albanians and founder of the independent state of Kosovo. Outside of the Albanian realm, however, he is little known as a literary scholar. It is this second dimension that we aim at imparting here beyond the Albanian public opinion, as Dr. Ibrahim Rugova is one of the greatest modern Albanian scholars.

As a literary scholar Rugova was shaped in the spirit of modern literary theories, those of the 2oth century, starting from Russian formalism, semiotics, structuralism, and post-structuralism. Erudition of these methods is articulated within the scope of Rugova's views and manifested in his work at the theoretical and result-oriented level.

The study of Ibrahim Rugova's theoretical-literary work by us, in fact, is an act of recognition of perhaps the greatest Albanian cultural and literary modernity work, which involves some of the fundamental problems of the theory of modern Albanian literature and universal literary criticism.

Rugova started his career as a scholar and literary interpreter with "The Lyrical Touch" (1971); he continued as an essayist, became a theoretician in the literary culture of Kosovo, and ultimately he moved to interpretation of cultural and political ideas, especially in his "Aesthetic Rejection" (1987), which happens to be his last work. So, the name of Ibrahim Rugova is linked to the development of 
modern Albanian contemplation on literature and culture, modern Albanian literary criticism, literary theory, and the national life as well, because he was the leader of the Kosovo Albanians in their strive for freedom and independence.

\section{Profile}

Ibrahim Rugova was born in 1944, in Cërcë, Istog (Kosova). He completed his studies in Albanian Language and Literature at the University of Prishtina. He also studied literature in Paris and in Zagreb. He gained his doctorate degree at the University of Prishtina in 1984.

In 1996, Ibrahim Rugova was elected a correspondent member of the Kosovo Academy of Sciences and Arts. On the same year he was awarded the Doctor Honoree Causa from the Paris VIII University, Paris. In 2004 Rugova was awarded the Doctor Honoree Causa from the University of Tirana.

For a long time, Ibrahim Rugova worked at the Pristina Institute of Albanian Studies as a researcher of literature. For some time, he was the editor-in-chief of the Institute's journal, "Albanological Research." He also was chairman of the Association of Kosovo Writers (Hamiti: 2007).

Ibrahim Rugova published the following works: "The Lyrical Touch" (1971), "Toward Theory" (1978), "Literary Criticism" (1979), "Strategy of Understanding" (1982), "Bogdani's Oeuvre 1675-1685" (1982), "Directions and Premises of Albanian Literary Criticism 1504-1983" (1986) and "Aesthetic Rejection" (1987)

Rugova's work as a literally scholar started with his "Lyrical Touch", which features almost all poetic literary interpretations, to follow with his "Toward Theory", which sets off Rugova's path to theoretical-literary research. Specifically, the problem treated in this book captures theoretical problems of literature and centered on the proposal for "artistic text" and "open work" (Eco: 1965) which proves that Rugova never intended to close the discussed issues, but aims at providing possible solutions (Shala, Shehri, Hyseni, Mehmetaj: 2012).

In this sense, his theory goes to the point of view of literature as "differentia specifica," as a special artistic product. In the case of this concept, apart from treating it theoretically, Rugova breaks it apart from Albanian literature, comparing it with the models of world knowledge. Such an effort seeks to differentiate literature as a particular gender, as an intellectual product, as quest of the "literary essence".

Essays, criticism, and literary theory are the genres of Rugova's subsequent work, "Strategy of Understanding". In essayist texts Rugova deals with literary phenomena; in critical texts he evaluates certain works; while in the theoretical texts Rugova summarizes the results of the research done in the first two fields (Shala: 2008). At the first chapter of the book, through essays, he lays the ground to clarify the research for the other two parts. Thus, he starts from the view that "strategy" should be understood as "mechanism", "regulator of meanings" and that can be manifested in many different forms. Hence, the strategy is called a "mechanism", producer and creator in the process of creating an artistic work.

"Bogdani's Oeuvre 1675-1685" is the most renowned work of Rugova, in which he deliberates on the author (Pjetër Bogdani), but also, according to him, analyzes his literary era. Rugova initially presents the work, and then he analyzes it, so the result stems from a long and systematic research.

Rugova himself finds Bogdani's discovery as an important "moment," as a landmark event in Albanian culture as it is a work that implies research into wide a range of fields: philosophicalscientific, philosophical-theoretical, research in various rhetoric issues, and some aspects of poetry.

In a short discourse, Bogdani's work, in the Rugova's study, links Albanian culture with the European culture of the time. The work is considered as a kind of an "Albanian Divine Comedy" in view of historical-literary and philosophical value and a basic work of the Albanian humanism.

The other critical study, "Directions and the Premises of Albanian Literary Criticism 1504-1983", is a kind of Albanian encyclopedia and typology of literary criticism. The basic result of this work is examination of the main elements on which the Albanian criticism has built its own assessment 
criteria, and then based on these, "directions" and "premises" are sought.

This study distinguishes the effort to look at the problem of criticism in the process of durability of ideas and the effort for literary research, then classification by form and method. "Directions and the Premises of Albanian Literary Criticism 1504-1983" is considered as the most renowned literary criticism work in the history of Albanian literature to date.

In 1987, Ibrahim Rugova published his last book, "Aesthetic Rejection", which resembles the structure and methods of the "Strategy of Understanding". Rejection or refusal, as a category of aesthetics and philosophy (Lamargue, Hugen: 2004), here is explained as a rebellion against the imposed, as a road that leads to building of democracy and creative freedom. Recognizing the relationship between literature and the world, in the "rejection," Rugova sees and analyzes the relation between literature and politics. In this context, the greatest rejection is regarded as "aesthetic rejection", which means literary work rejection with "being", with its "nature".

Thus, "aesthetic rejection" also affects the historical cultural order. Rugova's ultimate goal is to preserve the grounds through "aesthetic rejection", so that literature remains "the real literature", affecting the power and the society, not the other way around.

\section{Literary Criticism}

Bering in mind all of the issues that Ibrahim Rugova examines and aware of their importance, in a paper like this one, it is necessary to follow an internal typology of Rugova's study related to the interests of the scholar, but also the genres and fields of study. Thus, Rugova's work can be classified into four large entities, defined as:

I. Literary theory,

II. Essays,

III. Literary criticism and

IV. Studies and monographic books.

Rugova's second book, "Toward Theory", falls into the first group, as study that determined his path in literary studies. From the very beginning, Rugova raises a number of theoretical issues that are also paradigms of this author's literary theory. Literary theory is Rugova's beloved field, to which he returned whenever he intended to generalize the results from particular works and groups of works into theoretical concepts.

Essayistic aspect leaves traces in all critical oeuvre of Ibrahim Rugova, since his nature of a liberal scholar conforms most to the essay, a form extending everywhere in Rugova's literary studies.

Rugova's literary criticism excels especially when reading contemporary authors, in the first readings of their works. He is measured with these works, presents and evaluates them in the difficult path of first estimation, which is always the most difficult.

The critic's uniqueness lies in the fact that he appears as a powerful interpreter of literary knowledge and beyond, as a scholar in a quest of deep understanding of literature. This is shown in the works of the third category, namely in "literary criticism" (Fraj: 1990); (Lenticchio, McLonghlin: 1995).

Rugova will strongly prove this plurality of literary knowledge in two monographic books: "Bogdani's Oeuvre 1675-1685" and "Directions and the Premises of Albanian Literary Criticism 15041983 ”. Erudition of this thinker will take shape by merging into the entirety of these two monographic books.

\section{The Main Works}

Rugova's "Bogdani's Oeuvre..." is a result of an systematic research. While doing a research of the Albanian criticisms, Rugva "found" Pjetër Bogdani's work, amomg the greatest works of Albanian culture. For Rugova, this discovery marks a important moment and a great event.

Pjetër Bogdani's "Cunesu Prophetarum", which is the first Albanian literary script, has inspired 
emotions and enthusiasm. And, towards this path, in investigating and disaggregating the meaning of Bogdan's work today, Rugova emreges as the most important scholar. Bogdan's text is merged into the Rugova's text. All of these features of the Rugova's study will be discussed below, while now we turn to the context in which he reveals this work and the intent of affirming it in the 1980s.

Rugova's recognition of Bogdan's work is the result of a sensitory-semantic process, while motivation as a fascination after reading the work. Fascination justifies rationality, justifies its work and complexity. So, Rugova in communication with Bogdani follows the path from the idea-intuition to the criticism of the work, so that sub-objectivity takes the feature of objectivity. If the scholar, Rugova, is fascinated with this work, one has to consuider that we are dealimg with a magnificent piece of work (Mehmetaj: 2013).

Departing fom this idea we started studying the great work of Rugova, studying Bogdan's great work. All phenomena discovered open in Rugova's structural methodological method. Thus, Rugova studies the work thoroughly, explores its genetics, to then interpret the analytics. This means, his looking at "Cuneus..." will once be evocative, then analytical, with a bigger focus on this part. Rugova's genetic investigation creates greater opportunities for analyzing poetics or analytics. Genetics here is used as a mechanism of poetry.

In his stydy, Rugova's follows Robert Erns Curtius's „European Literature and the Latin Mediation", a reference that is realized more in the first part of the book, knowing that the search has more philological character, Sade, Fourier, Loyola and Bart, referred to in the second part of the text when analyzing it as a structural literary book, and the "Poetics of the old Russian literature“ by Lihačov. The author emphasizes more specifically that the authors are mentioned as a methodological basis to reinforce the provision of information about the work, intending to put it into theoretical contexts of contemporary theoretical and literary results.

Since the original aim of the Bogdani's works was affirmation of the book in Pristina in the 1980 , as the work was little known to the public, the author pursues a methodological principle that the problem of the work should not be related only to its historical context. So, the aim is the main plan of action, a profound indepth plan, which is argued through internal analysis. For Rugova, the foundation is updating Bogdan's ideas and problems, in a contemporary context. He chooses this as a way of modernizing terminology and discipline, so that the ideas and problems of Bogdan's work do not lose in essence.

Rugova, feeling deeply for Bogdan's work and "moments", examines its basic points from the critical and theoretical-literary viewpoint. Finally, searching for every sign of Bogdan's text before entering into analysis and interpretation, enriches us with the type of research, with the old language and style of Albanian writing.

The second major work, "Directions and Premises of Albanian Literary Criticism 1504-1983" is Dr. Rugova's second monographic, which encapsulates the problems of literary criticism and its interconnection with the history of literature and the theory of Albanian literature. The purpose of defining Albanian criticism from the beginning to the time of the author, with all the problems, conditions, and circumstances, has motivated the author to name his path and premises. Meanwhile, the authors' orientations and interests are directed towards critical methods, while the premise implies theoretical basics and results of the criticism in the historical and the actual context. In essence, the title justifies the conception of criticism as a theoretical and historical problem and determines Rugova's search that in the historical context investigate part of the chaos and premises of Albanian criticism, and further on examined and differentiated.

The treatment of the problem that Rugova has tackled, namely classification of the fields and the premise, both in the theoretical and in the historical plan, coincides with similar European treatments. Precisely, the author himself encompasses such issues with different perspectives in the regions. In order to be closer to the point of view of the world knowledge, especially the contemporary criticism, he also examines the classification of issues, types of criticism in the contemporary era. Thus, Rugova on this point creates a contextual understanding of the problem of observation, concluding that despite plurality of classifications and definitions of criticism, 
classification in the contemporary era is based on different methodologies used for literary criticism. In this respect, Rugova considers that this contemporary methodological plurality speaks of an interdisciplinary approach, which places some kind of correlation between the types of criticism, seen as communication in terms of results rather than methodologies. This critical type seems to be applied more to Zenith and Todorov, and especially to the exercise of their complementariness, the disparity between criticism and poetics, as well as the dialogic criticisms.

When speaking about theoretical literacy, he explains this best by referring to Welek's and Woren's theory, and he considers that the contemporary definition of these disciplines emerges, "through which the development of critical thinking in the historical order and the extraction of theoretical generalizations are contemplated in the plan historical look and plan of the current development of criticism."

Thus, in the context of these thoughts, evaluating the theorization of Welek and Woren and the interdisciplinary approach of Gennette and Todorov's "dialogue criticism", Rugova touches on the problem of the theoretical basis of Albanian literary criticism and the problem of their approach to differentiated methods, towards an examination of the method in literary criticism. Therefore, in explore Albanian literary criticism, Rugova seeks out the terms and conditions by testing them in two parts of the book, which divide them into two big entities: the beginnings of critical thought and contemporary criticism. Specifically, the development of our critical thinking generally requires a historical periodization to see their evolution in different periods of criticism, such as: National Revival Criticism, Criticism of 1912-1944, and then contemporary Criticism, which he shares in Criticism in Albania, Albanian Criticism in Kosovo and Criticism of Italo-Albanian (arbëresh). Each period, except for theoretical methods and theories, also explains the socio-cultural contexts that have determined the course of Albanian literary criticism.

The end result of Rugova's work is investigation of the main elements on which critics have built their own criteria, then on the basis of these premises are sought directions and directions. The path followed by Rugova to achieve this result is analytical, characterizing and evaluative look of books of criticism and criticism. The importance of such work is added in the first place given that literary criticism has never been conducted within such a long period of time. Thus, in the first part of the study, the effort to consider the problem of criticism in the process of continence of ideas is evident and clearly visible, while in the second part the effort for research and study of literature (which was partially known) was marked, followed by classification according to the form and method. But, in the preface of the book, Rugova states that "criticism will be taken into account as a study of literature on the historical and current plan."

Rugova's focal interest when classifying the periods is not classification of typological character, but rather classification in chronological orientation plan. In this way, his critical attitude supports the systematic presentation of premises at the "long diachronic" way (Bart: 1986)

It is worth noting that Rugova has looked at all critics who have contributed to the development of our criticism, regardless of ideological criteria that could eliminate them. He invites the way and the premise to be understood in the context of time, not from today's viewpoints of criticism. To avoid any misunderstanding, it clearly states that "if we start from the ideology of today's deliberations in the appreciation and orientation of the tradition with such a negative attitude, we fall into the denial of what stand on."

\section{Conclusions}

It should be noted that since Ibrahim Rugova's literary knowledge derives from "modern literary theory" (Calinescu: 2012), the discourses that describe modern theory as well should be used in studying his work.

A formalist and structuralist scholar, as was Rugova, seeks to trace the analytical method. As a semiologist, Rugova seeks to investigate his sign reading. As a post-structuralistic scholar (Culler: 1983), Rugova wants to read on the principle of "appreciation" to see how contemporary his work 
today is if it has the values of a "classical work" of modernity.

Rugova's literary criticism excels especially when reading contemporary authors. He is measured with these works, presents and evaluates them in the difficult path of first estimation, which is always the most difficult.

The critic's uniqueness lies in the fact that he appears as a powerful interpreter of literary knowledge and beyond, as a scholar in a quest of deep understanding of literature and this is shown in the works of the third category, namely in literary criticism.

The format and results of Rugova's literary studies can present by analyzing his two main works: "The Work of Bogdani 1675-1685" and "Directions and Premises of Albanian Literary Criticism 15041983 ".

Pjetër Bogdani's "Cunesu Prophetarum" (1685) has inspired emotions and enthusiasm and, towards this path, in investigating and disaggregating the meaning of Bogdan's work today, Rugova emreges as the most important scholar. All of features of the Rugova's study will be discussed below, while now we turn to the context in which he reveals this work and the intent of affirming it in the 1980s. As we undelined Rugova's recognition of Bogdan's work is the result of a sensitory-semantic process, while motivation as a fascination after reading the work. Fascination justifies rationality, justifies its work and complexity. So, Rugova in communication with Bogdani follows the path from the idea-intuition to the criticism of the work, so that sub-objectivity takes the feature of objectivity.

"Directions and Premises of Albanian Literary Criticism 1504-1983" encapsulates the problems of literary criticism and its interconnection with the history of literature and the theory of Albanian literature.

The purpose of defining Albanian criticism from the beginning to the time of the author, with all the problems, conditions, and circumstances, has motivated the author to name his path and premises. Meanwhile, the authors' orientations and interests are directed towards critical methods, while the premise implies theoretical basics and results of the criticism in the historical and the actual context. In essence, the title justifies the conception of criticism as a theoretical and historical problem and determines Rugova's search that in the historical context investigate part of the chaos and premises of Albanian criticism, and further on examined and differentiated.

\section{References}

Lamarque, P. and Haugon, S. (2004). Aesthetics and the Philosophy of Art. Oxford: Blackwell Publishers.

Bart, R. (1986). Aventura semiologjike. Prishtinë: Rilindja.

Calinescu, M. (2012). Pesë fytyrat e modernitetit. Tiranë: Dituria.

Lentricchio, F. and McLonghlin, Th. (1995). Critical Terms for Literary Study. Chicago and London: The University of Chicago Press.

Culler, J. (1983). Criticism after Structuralism. London and Melburn: Routledge \& Kegan Paul.

Eco, U. (1965). Otvoreno djelo, Sarajevo: Veselin Masleša.

Hajdegger, M. (1971). Poetry, Language, Thoughtt. New York: Hague \& Row Publishers. Velek, R., Voren, O. (1982). Teoria e letërsisë. Prishtinë: Rilindja.

Hamiti, S. (2007). Memento për Rugovën. Tiranë: 55.

Fraj, N. (1990). Anatomia e kritikës, Prishtinë: Rilindja.

Singer, A. and Dunn, A. (edited). (200o). Literary Aesthetics. Oxford: Blackwell Publishers.

Lodge, D. (edited). (1972) $.20^{\text {th }}$ Century Literary Criticism, London: Longman.

Mehmetaj, A. (2013). Semiologjia ime. Prishtinë: Buzuku.

Shala, K. .M. (2008). Rugova meditans, Prishtinë: Buzuku.

Shala, K. M., Shehri, Dh., Hyseni, M., Mehmetaj, A. (2012). Rugova i letërsisë. Prishtinë: Fondacioni Ibrahim Rugova.

\section{Research Corpus}

Rugova, I. (1971). Prekje lirike. Prishtinë: Rilindja.

Rugova, I. (1978). Kah teoria. Prishtinë. Rilindja. 
Rugova, I. (1979). Kritika letrare. Prishtinë: Rilindja.

Rugova, I. (1982). Strategjia e kuptimit. Prishtinë: Rilindja.

Rugova, I. (1982). Vepra e Bogdanit 1675-1685. Prishtinë: Rilindja.

Rugova, I. (1986). Kahe dhe premisa të kritikës letrare shqiptare 1504-1983. Prishtinë: Rilindja.

Rugova, I. (1987). Refuzimi estetik. Prishtinë: Rilinjda.

"Rugova, I. :"The Lyrical Touch" (1971), “To the Theory" (1978), "Literary Criticism" (1979), "Strategy of Understanding” (1982), "The Work of Bogdani 1675-1685" (1982), “Directions and Premises”, “Aesthetic Rejection”. 